\title{
KEBUTUHAN PENYANDANG DISABILITAS TUNARUNGU DI JABODETABEK TERHADAP LAYANAN SARANA DAN PRASARANA TRANSPORTASI KOTA
}

\author{
Gandhiko Ariya ${ }^{1}$ dan Leksmono Suryo Putranto ${ }^{2}$ \\ ${ }^{1}$ Program Studi Sarjana Teknik Sipil, Universitas Tarumanagara, Jl. Letjen S. Parman No.1 Jakarta \\ gandhiko.325150135@stu.untar.ac.id \\ ${ }^{2}$ Jurusan Teknik Sipil, Universitas Tarumanagara, Jl. Letjen S. Parman No.1 Jakarta \\ lexy_putranto@gmail.com
}

Masuk: 17-01-2020, revisi: 04-02-2020, diterima untuk diterbitkan: 05-02-2020

\begin{abstract}
Hearing impairments is the most frequent sensory deficit in human population, affecting more than 250 million people in the world. People with hearing impairments will find it difficult to use public transportation. Public transportation facilities and infrastructure should be accessible for everyone including for people with hearing impairments. This research paper will discuss about the level of importance and the level of availability at public transportation facilities and infrastructure for people with hearing impairments in Jabodetabek. This research paper will use Analytical Hierarchy Process (AHP) method in determining the level of importance at public transportation facilities and infrastructure and will use one sample t-test method in determining the level of availability at public transportation facilities and infrastructure in Jabodetabek. Based on the research result, emergency instruction is the most needed facilities for person with hearing impairment when using public transportation. Lighting is the most important facilities at public transportation infrastructure and public access to public transportation infrastructure for person with hearing impairments. Based on the research result, the level of availability for public transportation facilities and infrastructure in Jabodetabek is mostly quite available.
\end{abstract}

Keywords: Hearing Impairments; Public Transportation; Facilities and Infrastructure.

\begin{abstract}
ABSTRAK
Gangguan pendengaran merupakan gangguan sensorik yang paling banyak dialami oleh manusia. Lebih dari 250 juta orang di dunia mengalami gangguan pendengaran. Manusia dengan gangguan pendengaran akan merasa kesulitan saat ingin menggunakan transportasi perkotaan. Sarana dan prasarana sudah seharusnya aksesibel untuk semua orang termasuk untuk para penyandang disabilitas tunarungu. Penelitian ini akan membahas tentang tingkat kepentingan serta tingkat ketersediaan sarana dan prasarana transportasi kota di Jabodetabek bagi para penyandang disabilitas tunarungu. Penelitian ini akan menggunakan metode Analytical Hierarchy Process (AHP) dalam menentukan tingkat kepentingan sarana dan prasarana transportasi kota bagi para penyandang disabilitas tunarungu dan menggunakan one sample t-test untuk menentukan tingkat ketersediaan sarana dan prasarana transportasi kota di Jabodetabek. Berdasarkan hasil penelitian petunjuk keadaan darurat menjadi hal terpenting pada sarana transportasi kota, lampu penerangan menjadi hal terpenting pada prasarana dan prasarana pejalan kaki pada transportasi kota. Tingkat ketersedian sarana dan prasarana transportasi kota di Jabodetabek sudah cukup tersedia.
\end{abstract}

Kata kunci: Disabilitas Tunarungu; Transportasi Kota; Sarana dan Prasarana 


\section{PENDAHULUAN}

\section{Latar belakang}

Menurut Organisasi Kesehatan Dunia (World Health Organization) gangguan pendengaran adalah gangguan sensorik yang paling sering terjadi pada manusia. Lebih dari 250 juta orang di dunia mengalami gangguan pendengaran. Konsekuensi dari gangguan pendengaran meliputi ketidakmampuan untuk menangkap suara ucapan, sering kali mengakibatkan pengurangan kemampuan untuk berkomunikasi, keterlambatan dalam penguasaan bahasa, dirugikan pada bidang ekonomi dan pendidikan, dikucilkan dan distigmatisasi.

Manusia dengan gangguan pendengaran akan merasa kesulitan saat ingin menggunakan transportasi perkotaan. Hal ini dikarenakan mereka tidak dapat berkomunikasi secara normal dengan orang lainnya. Mereka biasanya mengandalkan indera penglihatan saat berada di tempat umum. Maka dari itu mereka akan bergantung dengan informasi yang bebentuk tulisan maupun gambar untuk dapat mereka mengerti.

Pemerintah Indonesia sudah berjanji untuk berpartisipasi dalam menghormati, melindungi, memenuhi, dan memajukan hak-hak penyandang disabilitas, yang pada akhirnya diharapkan dapat memenuhi kesejahteraan para penyandang disabilitas. Hal ini ditunjukkan oleh ditandatanganinya Konvensi Mengenai Hak-Hak Penyandang Disabilitas (Convention on the Rights of Persons with Disabilities) oleh pemerintah Indonesia pada tanggal 30 Maret 2007 di New York. Hal ini juga diperkuat oleh dibuatnya UU No.19 tahun 2011 Tentang Pengesahan Convention On The Rights Of Persons With Disabilities (Konvensi Mengenai Hak-Hak Penyandang Disabilitas).

Sarana dan prasarana sudah seharusnya aksesibel untuk semua orang termasuk para penyandang disabilitas. Karena sarana dan prasarana pada umumnya berguna untuk memenuhi kebutuhan setiap orang yang berada di tempat umum.

\section{Batasan masalah}

Batasan masalah pada penelitian ini adalah:

1. Penyandang disabilitas pada penelitian ini dibatasi pada penyandang disabilitas tunarungu.

2. Sarana transportasi kota pada penelitian ini dibatasi pada kereta KRL Commuter Line Jabodetabek yang berada di kota Jakarta, Bogor, Depok, Tangerang, dan Bekasi; Bis Transjakarta yang berada di kota Jakarta; dan kereta MRT Jakarta yang berada di kota Jakarta.

3. Prasarana transportasi kota pada penelitian ini dibatasi pada kereta KRL Commuter Line Jabodetabek yang berada di kota Jakarta, Bogor, Depok, Tangerang, dan Bekasi; Bis Transjakarta yang berada di kota Jakarta; dan kereta MRT Jakarta yang berada di kota Jakarta.

4. Prasarana pejalan kaki pada penelitian ini dibatasi pada akses responden dari rumah menuju stasiun atau halte dengan menganggap bahwa seluruh responden berjalan kaki.

\section{Rumusan masalah}

Masalah-masalah yang dapat dirumuskan pada tugas akhir ini adalah sebagai berikut:

1. Sarana, prasarana, dan prasarana pejalan kaki tranportasi kota apakah yang paling dibutuhkan oleh para penyandang disabilitas tunarungu?

2. Apakah sudah tersedia sarana, prasarana, dan prasarana pejalan kaki transportasi kota?

\section{Tujuan penelitian}

Tujuan dari penelelitian ini adalah:

1. Mengetahui tingkatan jenis kebutuhan fasilitas umum untuk para penyandang disabilitas tunarungu di sarana dan prasarana transportasi kota.

2. Mengidentifikasi dan mengevaluasi keadaan eksisting fasilitas umum di sarana dan prasarana transportasi kota yang dibutuhkan para penyandang disabilitas tunarungu di Jabodetabek.

\section{Penyandang disabilitas}

Menurut Kamus Besar Bahasa Indonesia (KBBI) penyandang diartikan sebagai orang yang menyandang (menderita) sesuatu, sedangkan disabilitas diartikan sebagai keadaan (seperti sakit atau cedera) yang merusak atau membatasi kemampuan mental dan fisik seseorang. Sehingga bila digabungkan, penyandang disabilitas dapat diartikan sebagai orang yang menyandang sakit atau cedera yang merusak atau membatasi kemampuan mental dan fisik seseorang. 
Pengertian Penyadang Disabilitas menurut UU Nomor 19 Tahun 2011 Tentang Pengesahan Convention On The Rights Of Persons With Disabilities (Konvensi Mengenai Hak-Hak Penyandang Disabilitas) adalah mereka yang memiliki keterbatasan fisik, mental,intelektual, atau sensorik dalam jangka waktu lama di mana ketika berhadapan dengan berbagai hambatan, hal ini dapat menghalangi partisipasi penuh dan efektif mereka dalam masyarakat berdasarkan kesetaraan dengan yang lainnya.

Beberapa golongan penyandang disabilitas yang umum di Indonesia diantaranya adalah tunanetra (mengalami gangguan pada penglihatan), tunarungu (mengalami gangguan pada pendengaran), tunawicara (mengalami gangguan bicara), tunadaksa (mengalami gangguan pada pergerakan), tunagrahita (mengalami keterbelakangan mental), tunalaras (mengalami gangguan emosi), tunaganda (mengalami gangguan lebih dari satu jenis disabilitas).

\section{Penyandang disabilitas tunarungu}

Organisasi Kesehatan Dunia mengklasifikasi gangguan pendengaran menjadi beberapa tingkatan yang bisa dilihat pada tabel 1.

Tabel 1. Klasifikasi gangguan pendengaran menurut organisasi kesehatan dunia

\begin{tabular}{|c|c|c|}
\hline Tingkat Kerusakan & Nilai ISO Audiometrik & Deskripsi Kerusakan \\
\hline 0 (Tidak Rusak) & $\begin{array}{l}\text { Kurang Dari } 25 \text { dBHL dan } \\
\text { telinga yang lebih baik }\end{array}$ & $\begin{array}{c}\text { Tidak mempunyai kerusakan atau sangat sedikit } \\
\text { mengalami kerusakan. Dapat mendengar suara bisikan }\end{array}$ \\
\hline 1 (Sedikit Rusak) & $\begin{array}{l}\text { 26-40 dBHL dan telinga } \\
\text { yang lebih baik }\end{array}$ & $\begin{array}{l}\text { Dapat mendengar dan mengulang ucapan yang } \\
\text { diucapkan dengan suara normal dari jarak } 1 \text { meter }\end{array}$ \\
\hline 2 (Cukup Rusak) & $\begin{array}{l}\text { 41-60 dBHL dan telinga } \\
\text { yang lebih baik }\end{array}$ & $\begin{array}{c}\text { Dapat mendengar dan mengulang ucapan yang } \\
\text { diucapkan dengan suara yang dikeraskan pada jarak } 1 \\
\text { meter }\end{array}$ \\
\hline 3 (Rusak Parah) & $\begin{array}{l}\text { 61-80 dBHL dan telinga } \\
\text { yang lebih baik }\end{array}$ & $\begin{array}{c}\text { Dapat mendengar beberapa kata saat diteriakkan pada } \\
\text { telinga yang lebih baik }\end{array}$ \\
\hline $\begin{array}{l}4 \text { (Rusak Sangat Parah, } \\
\text { termasuk ketulian) }\end{array}$ & $\begin{array}{c}\text { Lebih dari } 81 \mathrm{dBHL} \\
\text { dan telinga yang lebih baik }\end{array}$ & $\begin{array}{l}\text { Tidak dapat mendengar dan mengerti walaupun } \\
\text { dengan suara yang diteriakkan }\end{array}$ \\
\hline
\end{tabular}

(Sumber: WHO, 2003)

\section{Aksesibilitas penyandang disabilitas tunarungu pada sarana dan prasarana transportasi kota}

Aksesibilitas mempunyai pengertian sebagai kemudahan seseorang dalam mengakses suatu tempat. Sarana mempunyai pengertian segala sesuatu yang dipakai sebagai alat dalam suatu proses menuju tujuan yang diinginkan, sedang prasarana mempunyai arti segala penunjang utama dalam menuju tujuan yang diinginkan. Menurut KBBI sarana adalah segala sesuatu yang dapat dipakai sebagai alat dalam mencapai maksud dan tujuan, sedangkan prasarana adalah segala sesuatu yang merupakan penunjang utama terselenggaranya suatu proses. Aksesibilitas menjadi hal yang sangat penting dalam kegiatan transportasi umum, karena tujuan utama dari transportasi kota adalah menyediakan layanan untuk semua masyarakat.

Perencaan transportasi umum didasarkan terhadap kebutuhan untuk semua pengguna jasa. Perspektif tersebut juga berlaku untuk perencanaan informasi perjalanan di lingkungan transportasi umum yang direncanakan secara general dibandingkan secara individual walaupun kebutuhan informasi perjalanan merupakan kebutuhan individual. Informasi perjalanan untuk orang lanjut usia dan penyandang disabilitas harus sesuai dengan kebutuhan orang lain yang memiliki kebutuhan informasi yang serupa sehubungan dengan aksesibilitas. Pada perencanaan informasi perjalanan kekurangan secara individual tidak dapat berlaku, dikarenakan hal itu tidak mungkin dilakukan untuk setiap keadaan yang berbeda. Perencanaan informasi perjalanan dibuat secara objektif untuk semua masalah yang dihadapi oleh seluruh kelompok orang dengan keterbatasan secara keseluruhan.

(Waara et al ., 2015)

PT KCJ terus meningkatkan pelayanan KRL untuk penumpang dengan disabilitas. Sejumlah inovasi maupun standar pelayanan telah dipenuhi demi memperbaiki aksesibilitas stasiun dan KRL. Informasi visual saat ini telah tersedia bagi pengguna dengan disabilitas di dalam KRL. Pengguna akan mudah menemukan informasi melalui layar Sistem Informasi Penumpang (SIP) yang terpasang di KRL, serta papan-papan petunjuk. Informasi yang tersedia antara lain mengenai stasiun berikutnya, tujuan akhir KRL, aturan dan larangan di dalam KRL, serta 
petunjuk keadaan darurat. Selain pengguna pada umumnya, pengguna KRL dengan disabilitas tuna rungu sangat terbantu dengan adanya media informasi ini.

Institute for Transportation Development Policy (ITDP) telah membuat panduan desain fasilitas pejalan kaki DKI Jakarta 2017-2022. Pada panduan tersebut, ITDP menyarankan adanya jalur khusus bagi pejalan kaki yang lengkap, aman, nyaman, dan humanis. ITDP menyarankan adanya trotoar dan tempat penyebrangan jalan yang baik. Trotoar sebaiknya dibuat senyaman mungkin dengan memberikan tempat yang teduh, lampu penerangan, serta petunjuk arah. Sedangkan tempat penyebrangan dibagi menjadi beberapa aspek. Tempat penyebrangan jalan dibagi menjadi zebra cross, jembatan penyebrangan orang, dan penyebrangan pada lampu lalu lintas.

\section{Metode analytical hierarchy process (AHP)}

AHP merupakan pendekatan dasar untuk pengambilan keputusan. AHP dirancang untuk mengatasi baik rasional maupun intuitif untuk memilih yang terbaik dari angka-angka atau alternatif-alternatif yang dievaluasi dengan beberapa kriteria. Pada proses ini, pembuat keputusan akan melakukan penilaian dengan cara perbandingan berpasangan yang kemudian digunakan untuk menentukan prioritas secara keseluruhan untuk menentukan peringkat dari angka-angka atau alternatif-alternatif. (Satty dan Vargas, 2012)

Matriks perbandingan berpasangan merupakan suatu matriks yang digunakan untuk menyatakan suatu pertimbangan antara dua elemen yang dibandingkan (Saaty, 1993). Matriks yang digunakan merupakan matriks bujur sangkar dengan banyak baris (dan kolom) sebagaimana kriteria yang dihubungkan dengan tujuan.

Angka dalam matriks ini mengekspresikan intensitas dari dominasi kriteria pada kolom sebelah kiri terhadap kriteria pada baris puncak. Matriks ini berupa matriks reciprocal, artinya angka yang simetrik berdasar diagonal utama adalah kebalikan satu sama lain. Dalam matriks ini, terdapat perbandingan dengan dirinya sendiri pada diagonal utama, maka perbandingan itu diberi angka satu (Saaty, 1993). Contoh Matriks berpasangan adalah seperti pada tabel. 2

Tabel 2. Contoh tabel matriks perbandingan berpasangan

\begin{tabular}{ccccc}
\hline$C$ & $A_{1}$ & $A_{2}$ & $\ldots \ldots$ & $A_{n}$ \\
$A_{1}$ & 1 & $a_{21}$ & $\ldots \ldots$ & $a_{1 n}$ \\
$A_{2}$ & $a_{12}$ & 1 & $\ldots \ldots$ & $a_{2 n}$ \\
$:$ & $:$ & $:$ & $\ldots \ldots$ & $\ldots \ldots$ \\
$A_{n}$ & $a_{n 1}$ & $a_{n 2}$ & $\ldots \ldots$ & 1 \\
\hline
\end{tabular}

(Sumber : Saaty, 1993)

Adapun pedoman untuk memberikan penilaian dalam perbandingan berpasangan yaitu dengan menggunakan skala perbandingan yang diusulkan oleh Thomas L. Saaty. Interval dalam perbandingan berpasangan tersebut antara satu sampai sembilan dengan masing-masing nilai mempunyai kriteria sendiri untuk dipilih. Skala perbandingan yang digunakan dalam AHP disajikan dalam Tabel 3 sebagai berikut :

Tabel 3. Skala banding berpasangan

\begin{tabular}{ccc}
\hline $\begin{array}{c}\text { Tingkat } \\
\text { Kepentingan }\end{array}$ & Definisi & Keterangan \\
\hline 1 & Sama penting & Kedua elemen mempunyai pengaruh yang \\
sama & Sedikit lebih penting & $\begin{array}{c}\text { Pengalaman dan penilaian sedikit } \\
\text { memihak satu elemen dibandingkan } \\
\text { dengan pasangannya }\end{array}$ \\
5 & Lebih penting & $\begin{array}{c}\text { Pengalaman dan penilaian sangat memihak } \\
\text { satu elemen dibandingkan dengan } \\
\text { pasangannya }\end{array}$ \\
& Sangat lebih penting & $\begin{array}{c}\text { Satu elemen lebih disukai dan secara } \\
\text { praktis dominasinya sangat nyata } \\
\text { dibandingkan dengan pasangannya }\end{array}$ \\
& Mutlak lebih penting & Satu elemen mutlak lebih disukai \\
& & dibandingkan dengan pasangannya pada \\
& tingkat keyakinan tertinggi
\end{tabular}


Tabel 3. Skala banding berpasangan (Lanjutan)

\begin{tabular}{|c|c|c|}
\hline $\begin{array}{l}\text { Tingkat } \\
\text { Kepentingan }\end{array}$ & Definisi & Keterangan \\
\hline $2,4,6,8$ & & $\begin{array}{l}\text { Diberikan bila terdapat penilaian antara } \\
\text { dua penilaian yang terdekat. }\end{array}$ \\
\hline Kebalikan & $a_{i j}=1 / a_{j i}$ & $\begin{array}{c}\text { Jika untuk aktivitas ke-i mendapatkan satu } \\
\text { angka bila dibandingkan dengan aktivitas } \\
\text { ke-j, maka } j \text { memiliki nilai kebalikannya } \\
\text { bila dibandingkan dengan } i\end{array}$ \\
\hline
\end{tabular}

(Sumber : Saaty, 1993)

Apabila matriks berpasangan adalah matriks perbandingan berpasangan yang konsisten, maka semua nilai eigen bernilai nol kecuali yang bernilai sama dengan $n$. Tetapi, bila matriks berpasangan adalah matriks tak konsisten akan membuat nilai eigen terbesar $\lambda$ max selalu lebih besar atau sama dengan $n: \lambda \max \geq n$. Perbedaan antara $\lambda$ max dengan $\mathrm{n}$ dapat digunakan untuk meneliti seberapa besar ketidakkonsistenan yang ada dalam matriks berpasangan tersebut, dimana rata-ratanya dinyatakan sebagai berikut :

$$
C I=\frac{\lambda \max -n}{n-1}
$$

Dimana $\mathrm{CI}=$ Consistency Index, $\lambda_{\max }=$ Nilai Eigen Maksimum, $\mathrm{n}=$ jumlah ordo matriks

Suatu matriks yang dihasilkan dari perbandingan secara acak merupakan suatu matriks yang mutlak tak konsisten. Dari matriks acak tersebut, didapatkan nilai Consistency Index yang disebut Random Consistensi Index (RI) (Saaty, 1993). Nilai Random Consistency Index (RI) disajikan pada Tabel 4 di bawah ini:

Tabel 4. Nilai random consistency index (RI)

\begin{tabular}{ccccccccccc}
\hline$N$ & 1 & 2 & 3 & 4 & 5 & 6 & 7 & 8 & 9 & 10 \\
\hline$R I$ & 0 & 0 & 0.52 & 0.89 & 1.11 & 1.25 & 1.35 & 1.4 & 1.45 & 1.49 \\
\hline
\end{tabular}

(Sumber: Saaty, 1993)

Dengan membandingkan CI dengan RI, didapat suatu acuan untuk menentukan tingkat konsistensi suatu matriks. Acuan tersebut adalah Consistency Ratio yang dirumuskan sebagai berikut (Saaty, 1993):

$$
C R=\frac{C I}{R I}
$$

\section{Dimana $\mathrm{CR}=$ Consistency Ratio, $\mathrm{CI}=$ Consistency Index, $\mathrm{RI}=$ Random Consistency Index}

Suatu tingkat konsistensi tertentu diperlukan dalam penentuan prioritas untuk mendapatkan hasil yang sah. Nilai $C R$ semestinya tidak lebih dari $5 \%$ untuk $n=3$, tidak lebih dari $8 \%$ untuk $n=4$, dan tidak lebih dari $10 \%$ untuk $n=5$. Jika tidak, penilaian yang telah dibuat mungkin dilakukan secara random perlu direvisi (Saaty, 1993).

\section{METODE PENELITIAN}

Alur atau tahapan dari penelitian ini tertera dalam bentuk diagram seperti pada gambar 1 dibawah ini. 


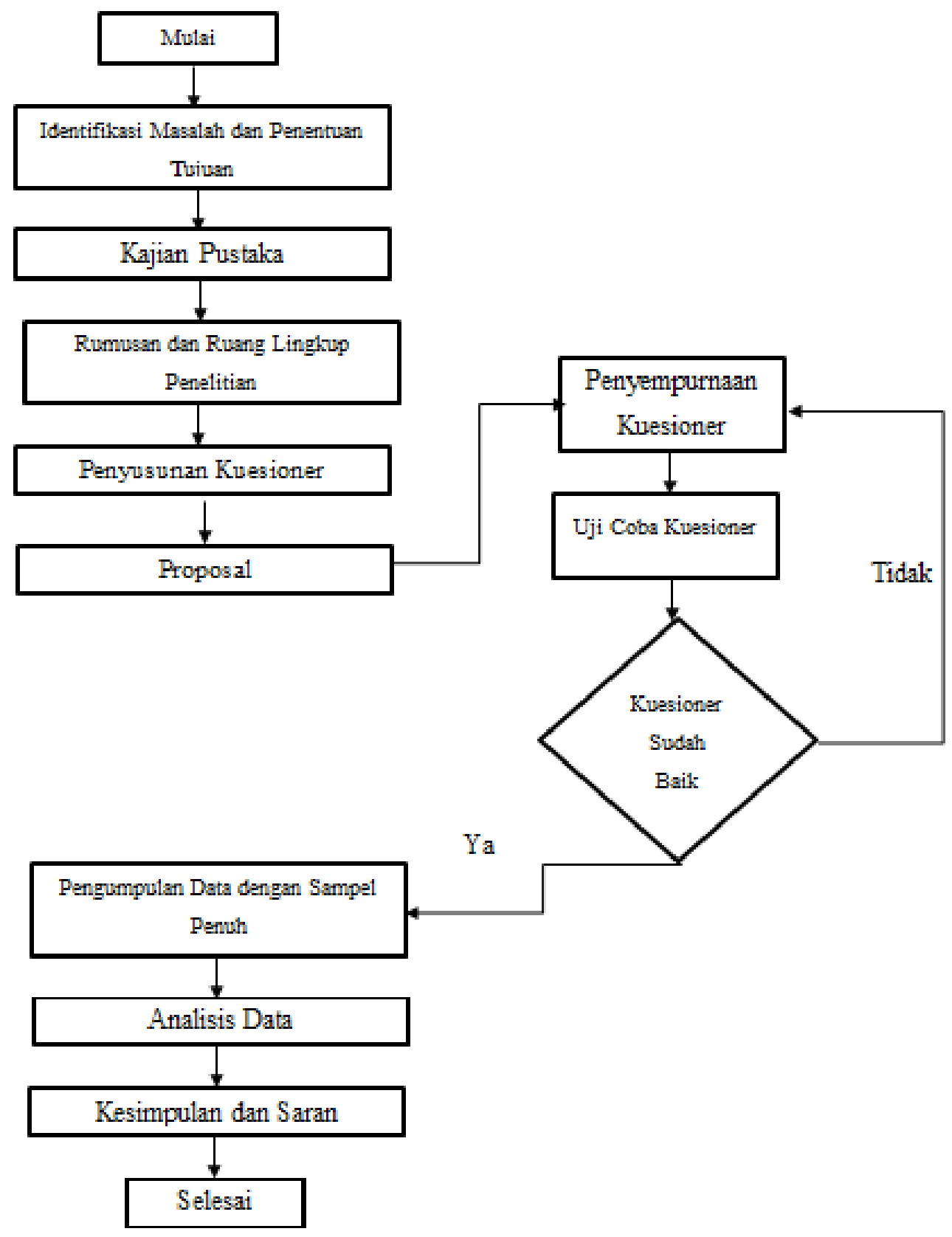

Gambar 1. Diagram alur penelitian

Subjek peneletian pada penelitian ini terdiri dari 2 jenis respoden yang berjumlah 35 orang yang terdiri dari 10 orang responden penyandang disabilitas tunarungu dan dalam melakukan kegiatan sehari-hari menggunakan alat transportasi kota (KRL Commuter Line Jabodetabek, Transjakarta, MRT Jakarta) serta 25 orang responden normal dan dalam melakukan kegiatan sehari-hari menggunakan alat transportasi kota (KRL Commuter Line Jabodetabek, Transjakarta, MRT Jakarta). Lokasi penelitian pada penelitian ini adalah kota Jakarta, Bogor, Depok, Tangerang, dan Bekasi (Jabodetabek). Daftar pertanyaan (kuesioner) dalam bentuk google forms dibuat untuk memperoleh data-data primer yang disusun berdasarkan parameter-parameter analisis yang dibutuhkan dan relevan sesuai dengan maksud dan tujuan dari penelitian ini yang ditujukan kepada responden yang sudah ditentukan sebelumnya.

Pengumpulan data dilakukan melalui kuesioner dengan pertanyaan yang berkaitan dengan tujuan dari penelitian ini. Pertanyaan tersebut didasari oleh Aspek dan Kriteria pada peneletian ini. Data yang diambil dari kuesioner ini adalah dimana keberadaan fasilitas umum yang paling penting, jenis fasilitas umum apakah yang lebih penting, serta eksisting fasilitas umum yang ada pada saat ini menurut para responden. 
Aspek pada peneletian ini adalah

- Sarana transportasi kota di Jabodetabek (Kereta KRL Commuter Line, Bis Transjakarta, Kereta MRT Jakarta)

- $\quad$ Prasarana transportasi kota di Jabodetabek (Stasiun KRL Commuter Line, Halte Transjakarta, Stasiun MRT Jakarta)

- Prasarana pejalan kaki menuju ke prasarana transportadi kota terdekat (Jalan dari rumah menuju ke stasiun atau halte terdekat, dianggap seluruh responden berjalan kaki)

Kriteria pada peneletian ini adalah

- $\quad$ Sarana transportasi kota di Jabodetabek

o $\quad$ Tempat duduk prioritas

o Informasi tempat

o Peta

o Petunjuk keadaan darurat

o Informasi aturan dan larangan

o Keberadaan petugas

- Prasarana transportasi kota di Jabodetabek

o $\quad$ Tempat duduk prioritas

o Informasi tiket

o Petunjuk arah

o Informasi kedatangan

o Lampu penerangan

o Keberadaan petugas

- $\quad$ Prasarana pejalan kaki

$\begin{array}{ll}\text { o } & \text { Trotoar } \\ \text { o } & \text { Jembatan penyebrangan orang } \\ \text { o } & \text { Zebra cross } \\ \text { o } & \text { Penunjuk arah } \\ \text { o } & \text { Lampu penerangan jalan } \\ \text { o } & \text { Lampu lalu lintas }\end{array}$

\section{Metode analisis data}

Analisis pada penelitian ini terbagi menjadi dua buah bagian yaitu penelitian untuk mengetahui tingkat kepentingan sarana, prasarana, dan prasarana pejalan kaki pada transportasi kota yang akan dianalisis dengan menggunakan metode analisis AHP (Analytic Hierarchy Process), serta penelitian untuk mengetahui ketersedian sarana, prasarana, dan prasarana pejalan kaki pada transportasi kota yang akan dianalisis dengan menggunakan metode analisis One Sample T-Test.

Metode analisis AHP (Analytic Hierarchy Process) akan dilakukan dengan menggunakan software Expert Choice. Metode analisis One Sample T-Test akan dilakukan dengan menggunakan software SPSS (Statistical Package for the Social Sciences).

\section{Distribusi responden}

Responden yang didapat dalam penelitian ini berjumlah 35 orang yang terdiri dari 10 orang responden penyandang disabilitas tunarungu dan 25 orang responden normal. Data-data yang terdapat dalam kuesioner adalah data umum berupa jenis kelamin responden, usia responden, pendidikan terakhir responden. Jenis kelamin akan dibagi 
menjadi dua kelompok yaitu laki-laki dan perempuan untuk masing-masing jenis responden. Usia akan diabgi per 10 tahun dimulai dari usia 20 tahun hingga 50 tahun untuk masing-masing jenis responden. Pendidikan terakhir responden akan dibagi menjadi 4 bagian yaitu SD, SMP, SMA/Kejuruan/Sederajatnya, dan Perguruan Tinggi untuk masing-masing jenis respondennya. Data umum responden dapat dilihat pada tabel 5 sampai tabel 7.

Tabel 5. Data jenis kelamin responden

\begin{tabular}{ccc}
\hline Jenis Responden & Jenis Kelamin & Jumlah \\
\hline \multirow{2}{*}{ Penyandang Disabilitas } & Laki-Laki & 6 \\
Tunarungu & Perempuan & 4 \\
& Jumlah & 10 \\
Normal & Laki-Laki & 13 \\
& Perempuan & 12 \\
& Jumlah & 25 \\
Gabungan & Laki-Laki & 19 \\
& Perempuan & 16 \\
\hline
\end{tabular}

Tabel 6. Data usia responden

\begin{tabular}{ccc}
\hline Jenis Responden & Usia & Jumlah \\
\hline \multirow{2}{*}{ Penyandang Disabilitas } & $20-29$ & 1 \\
Tunarungu & $30-39$ & 4 \\
& $40-50$ & 5 \\
Normal & $20-29$ & 11 \\
& $30-39$ & 5 \\
\multirow{2}{*}{ Gabungan } & $40-50$ & 9 \\
& $20-29$ & 12 \\
& $30-39$ & 9 \\
\hline
\end{tabular}

Tabel 7. pendidikan terakhir responden

\begin{tabular}{ccc}
\hline Jenis Responden & Pendidikan Terkahir & Jumlah \\
\hline \multirow{2}{*}{ Penyandang Disabilitas } & SD & 2 \\
Tunarungu & SMP & 1 \\
& SMA/Kejuruan/Setaranya & 5 \\
& Perguruan Tinggi & 2 \\
Normal & SD & 0 \\
& SMP & 0 \\
& SMA/Kejuruan/Setaranya & 4 \\
Gabungan & Perguruan Tinggi & 21 \\
& SD & 2 \\
& SMP & 1 \\
& SMA/Kejuruan/Setaranya & 9 \\
\hline
\end{tabular}

\section{HASIL DAN PEMBAHASAN}

Analisis tingkat kepentingan sarana, prasarana, dan prasarana pejalan kaki pada transportasi kota bagi para penyandang disabilitas tunarungu

Analisis ini bertujuan untuk mengetahui tingkat kepentingan pada sarana, prasarana, dan prasarana pejalan kaki yang ada di transportasi kota Jabodetabek (KRL Commuter Line, Transjakarta, MRT Jakarta) bagi para penyandang disabilitas tunarungu. Metode analisis yang digunakan pada bagian ini adalah metode analisis AHP (Analytic Hierarchy Process) dengan menggunakan software Expert Choice. 


\section{Sarana}

Pada bagian Sarana, ada 6 variabel yang diteliti untuk ditentukan variabel yang paling dibutuhkan oleh para penyandang disabilitas tunarungu pada sarana transportasi perkotaan (Kereta atau Bis). Variabel-variabel yang diteliti pada sarana transportasi kota adalah tempat duduk prioritas, informasi tempat, peta, petunjuk keadaan darurat, informasi aturan dan larangan, keberadaan petugas. Hasil dari tingkat kepentingan pada sarana transportasi kota dapat dilihat pada tabel 8. Tabel tersebut akan menampilkan hasil dari responden penyandang disabilitas tunarungu (responden khusus), responden normal, dan gabungan dari kedua responden tersebut.

Tabel 8. Hasil tingkat kepentingan pada sarana transportasi kota

\begin{tabular}{ccccccc}
\hline & Khusus & Rank & Normal & Rank & Gab & Rank \\
\hline Keberadaan Petugas & 0,405 & 1 & 0,146 & 4 & 0,204 & 2 \\
Petunjuk Keadaan Darurat & 0,180 & 2 & 0,226 & 1 & 0,221 & 1 \\
Informasi Tempat & 0,134 & 3 & 0,144 & 5 & 0,147 & 4 \\
Informasi Aturan dan Larangan & 0,105 & 4 & 0,126 & 6 & 0,126 & 6 \\
Peta & 0,089 & 5 & 0,154 & 3 & 0,137 & 5 \\
Tempat Duduk Prioritas & 0,087 & 6 & 0,204 & 2 & 0,166 & 3 \\
\hline
\end{tabular}

Pada tabel 10 bisa dilihat adanya perbedaan beberapa persepsi oleh para responden penyandang disabilitas tunarungu dan responden yang normal. Hal yang paling berbeda adalah pada bagian Keberadaan Petugas dan Tempat Duduk Prioritas. Para penyandang tunarungu berpendapat bahwa keberadaan petugas adalah hal yang paling mereka butuhkan saat menggunakan sarana transportasi kota. Keberadaan Petugas menduduki peringkat pertama dengan bobot 0,405 atau $40,5 \%$ sedangkan responden yang normal berpendapat bahwa keberadaan petugas tidak begitu penting untuk para penyandang disabilitas tunarungu dan berada di posisi ke 4 dengan bobot 0,146 atau $14,6 \%$. Hal kedua yang sangat berbeda persepsi antara kedua responden ini adalah Tempat Duduk Prioritas. Para penyandang disabilitas tunarungu menganggap bahwa tempat duduk prioritas bukanlah sesuatu yang penting bagi mereka. Bobot dari tempat duduk prioritas yang dihasilkan dari para penyandang disabilitas tunarungu hanyalah 0,087 atau $8,7 \%$ dan berada di posisi terakhir tingkat kepentingan yang mereka butuhkan. Hal ini berbeda dengan para responden normal yang berpendapat bahwa para penyandang disabilitas tunarungu membutuhkan tempat duduk prioritas. Para responden normal memberikan Tempat duduk prioritas dengan bobot 0,204 atau 20,4\% dan berada pada posisi ke 2 tingkat kepentingan hal yang dibutuhkan para penyandang disabilitas tunarungu. Selain 2 hal tersebut, bisa dikatakan bahwa penyandang disabilitas tunarungu dan para resonden normal mempunyai persepsi yang sama tentang apa yang para penyandang disabilitas tunarungu butuhkan saat menggunakan sarana transportasi kota. Hal ini dibuktikan dengan tidak berbeda secara signifikan hasil diantara keduanya mengenai hal-hal yang lainnya. Petunjuk Keadaan Darurat merupakan hal yang terpenting yang dibutuhkan oleh para penyandang disabilitas tunarungu dengan bobot yang diberikan oleh para penyandang disabilitas tunarungu adalah 0,201 atau $20,1 \%$ dan yang diberikan oleh para pengguna sarana yang normal adalah 0,221 atau $22,1 \%$.

\section{Prasarana}

Pada bagian Prasarana, ada 6 variabel yang diteliti untuk ditentukan mana variabel yang paling dibutuhkan oleh para penyandang disabilitas tunarungu pada prasarana transportasi perkotaan (Halte atau Stasiun). Variabelvariabel yang diteliti pada sarana transportasi kota adalah tempat duduk prioritas, informasi tiket, petunjuk arah, informasi kedatangan, lampu penerangan, keberadaan petugas. Hasil dari tingkat kepentingan pada prasarana transportasi kota dapat dilihat pada tabel 9. Tabel tersebut akan menampilkan hasil dari responden penyandang disabilitas tunarungu (responden khusus), responden normal, dan gabungan dari kedua responden tersebut.

Tabel 9. Hasil tingkat kepentingan pada prasarana transportasi kota

\begin{tabular}{ccccccc}
\hline & Khusus & Rank & Normal & Rank & Gab & Rank \\
\hline Keberadaan Petugas & 0,359 & 1 & 0,132 & 5 & 0,183 & 2 \\
Lampu Penerangan & 0,185 & 2 & 0,197 & 1 & 0,200 & 1 \\
Petunjuk Arah & 0,142 & 3 & 0,185 & 3 & 0,178 & 3 \\
Informasi Kedatangan & 0,127 & 4 & 0,164 & 4 & 0,157 & 5 \\
Informasi Tiket & 0,104 & 5 & 0,127 & 6 & 0,124 & 6 \\
Tempat Duduk Prioritas & 0,083 & 6 & 0,194 & 2 & 0,158 & 4 \\
\hline
\end{tabular}


Pada Tabel 11 dapat dilihat kembali adanya perbedaan pada persepsi para responden penyandang disabilitas tunarungu dengan para responden normal pada bagian ketersedian petugas dan tempat duduk prioritas. Hal ini sama seperti pada bagian sarana. Para responden penyandang disabilitas tunarungu berpendapat bahwa keberadaan petugas merupakan hal yang paling penting bagi mereka dengan memberi bobot 0,359 atau 35,9\%. Sedangkan para responden normal hanya memberi bobot 0,132 atau 13,2\% untuk keberadaan petugas. Tempat duduk prioritas juga kembali menjadi hal kedua yang terjadi perbedaan persepsi diantara responden dengan disabilitas tunarungu dan responden normal. Para responden penyandang disabilitas tunarungu memberikan bobot sebesar 0,083 atau $8,3 \%$ sedangkan para responden normal memberi bobot 0,194 atau $19,4 \%$. Lampu penerangan menjadi hal yang paling penting untuk para penyandang disabilitas tunarungu dimana kedua jenis responden sama sama memberikan bobot yang cukup besar untuk keduanya yaitu para penyandang disabilitas tunarungu memberikan bobot sebesar 0,185 atau $18,5 \%$ dan para responden normal memberi bobot sebesar 0,197 atau $19,7 \%$.

\section{Prasarana pejalan kaki}

Pada bagian prasarana pejalan kaki, ada 6 variabel yang diteliti untuk ditentukan mana variabel yang paling dibutuhkan oleh para penyandang disabilitas tunarungu pada prasarana pejalan kaki yang menghubungkan antara prasarana transportasi kota (Halte atau Stasiun) dengan rumah mereka. Variabel-variabel yang diteliti adalah trotoar, jembatan penyebrangan orang, zebra cross, penunjuk arah, lampu penerangan jalan, lampu lalu lintas. Hasil dari tingkat kepentingan pada prasarana pejalan kaki transportasi kota dapat dilihat pada tabel 10. Tabel tersebut akan menampilkan hasil dari responden penyandang disabilitas tunarungu (responden khusus), responden normal, dan gabungan dari kedua responden tersebut.

Tabel 10. Hasil tingkat kepentingan pada prasarana pejalan kaki transportasi kota

\begin{tabular}{ccccccc}
\hline & Khusus & Rank & Normal & Rank & Gab & Rank \\
\hline Lampu Penerangan Jalan & 0,223 & 1 & 0,189 & 2 & 0,201 & 1 \\
Lampu Lalu Lintas & 0,207 & 2 & 0,183 & 3 & 0,192 & 2 \\
Petunjuk Arah & 0,181 & 3 & 0,121 & 6 & 0,137 & 6 \\
Jembatan Penyebrangan Orang & 0,172 & 4 & 0,192 & 1 & 0,188 & 3 \\
Zebra Cross & 0,135 & 5 & 0,136 & 5 & 0,137 & 5 \\
Trotoar & 0,082 & 6 & 0,179 & 4 & 0,145 & 4 \\
\hline
\end{tabular}

Dari Tabel 12 bisa dikatakan persepsi yang cukup berbeda ada pada bagian jembatan penyebrangan orang dan petunjuk arah. Pada jembatan penyebrangan orang para responden normal menganggap bahwa para penyandang disabilitas tunarungu sangat membutuhkan jembatan penyebrangan orang, tetapi para penyandang disabilitas tunarungu mengangap bahwa jembatan penyebrang orang bukanlah hal yang sangat penting bagi mereka. Para penyandang disabilitas tunarungu hanya memberi bobot 0,172 atau $17,2 \%$ untuk jembatan penyebrangan orang dan berada pada posisi ke 4, sedangkan para responden normal memberikan bobot $0,192 \%$ atau $19,2 \%$ atau pada posisi pertama. Lampu Penerangan jalan merupakan hal terpenting yang dibutuhkan oleh para penyandang disabilitas tunarungu di prasarana pejalan kaki. Para penyandang disabilitas tunarungu dan juga responden normal memberi bobot yang cukup tinggi terhadap lampu penerangan jalan dengan para penyandang disabilitas tunarungu memberi bobot sebesar 0,223 atau 22,3\% dan berada pada posisi pertama sedangkan para responden nomal memberi bobot sebesar 0,189 atau 18,9\%. Sama seperti pada bagian prasarana, lampu penerangan kembali menjadi hal yang paling penting yang para penyandang disabilitas tunarungu butuhkan.

\section{Analisis tingkat ketersediaan sarana, prasarana, dan prasarana pejalan kaki pada transportasi kota bagi para penyandang disabilitas tunarungu}

Tingkat ketersediaan sarana, prasarana, dan prasarana pejalan kaki pada transportsi kota di Jabodetabek hampir seluruhnya sudah cukup tersedia. Pada bagian sarana di kereta KRL Commuter Line Jabodetabek. Para responden disabilitas tunarungu dan para responden normal pun dapat dikatakan mempunyai persepsi yang sama mengenai hal ini dikarenakan hasil rata-rata nilai kedua responden ini tidak berbeda jauh. Pada bagian ketersediaan sarana di bis Transjakarta juga seluruh responden menilai bahwa sarana di bis Transjakarta sudah cukup tersedia. Persepsi diantara responden penyandang disabilitas tunarungu dan responden normal juga cukup sama pada bagian ini. Pada bagian ketersediaan sarana di kereta MRT Jakarta para responden juga menilai bahwa ketersediaan sarana pada kereta MRT Jakarta sudah cukup tersedia. Bahkan para responden memberikan nilai yang paling tinggi untuk tingkat ketersediaan pada sarana kereta MRT Jakarta dibandingkan dengan sarana trasnportasi kota lainnya. Hal ini tentu merupakan suatuh hal yang baik mengingat kereta MRT Jakarta merupakan hal yang paling baru diantara transportasi kota lainnya. Pada bagian parasarana di satasiun KRL Commuter Line Jabodetabek para responden menyatakan bahwa prasarana di stasiun KRL Commuter Line Jabodetabek sudah cukup tersedia. Pada bagian ini 
juga para responden penyandang disabilitas tuanrungu dan para responden normal mempunyai persepsi yang sama dimana nilai yang diberikan keduanya tidak berbeda jauh. Pada bagian ketersediaan prasarana di halte Transjakarta, ada prasarana yang menurut para responden belum cukup tersedia. Prasarana tersebut adalah tempat duduk prioritas pada halte transjakarta. Selain tempat duduk prioritas, prasarana pada halte transjakarta sudah cukup tersedia. Perbedaan persepsi pun terjadi pada bagian ini, dimana para responden penyandang disabilitas tunarungu memberikan nilai yang cukup jauh lebih tinggi dari para responden normal untuk seluruh jenis prasarana pada halte Transjakarta. Pada bagian ketersediaan prasarana pada stasiun MRT Jakarta para responden menyatakan prasarana pada stasiun MRT Jakrta sudah cukup tersedia. Sama seperti bagian sarana, bagian prasarana MRT Jakarta juga mendapat nilai paling tinggi dari para responden dibandingkan dengan prasarana transportasi kota lainnya. Pada bagian prasarana pejalan kaki terdapat perbedaan persepsi antara responden penyandang disabilitas tunarungu dan responden normal. Banyak prasarana pejalan kaki yang dikatakan oleh apra responden normal belum cukup tersedia, berbeda dengan para responden disabilitas tunarungu yang mengatakan bahwa seluruh prasarana pejalan kaki sudah cukup tersedia, bahkan para responden disabilitas tunarungu memberikan nilai yang cukup tinggi pada ketersediaan prasarana pejalan kaki pada transportasi kota.

\section{KESIMPULAN DAN SARAN}

\section{Kesimpulan}

Berdasarkan penelitian yang telah dilakukan dapat disimpulkan sebagai berikut:

1. Berdasarkan hasil penelitian didapatkan tingkat kepentingan pada sarana, prasarana, dan prasarana pejalan kaki transportasi kota di Jabodetabek. Tingkat kepentingan pada bagian sarana adalah:
1) Petunjuk keadaan darurat
2) Keberadaan petugas
3) Tempat duduk prioritas
4) Informasi tempat
5) Peta
6) Informasi aturan dan larangan

Tingkat kepentingan pada bagian prasarana adalah:
1) Lampu penerangan
2) Keberadaan Petugas
3) Petunjuk Arah
4) Tempat duduk prioritas
5) Informasi kedatangan
6) Informasi tiket

Tingkat kepentingan pada bagian prasarana pejalan kaki adalah:
1) Lampu penerangan jalan
2) Lampu lalu lintas
3) Jembatan penyebrangan orang
4) Trotoar
5) Zebra cross
6) Petunjuk arah

2. Pada saat menentukan tingkat kepentingan, ada perbedaan persepsi antara responden penyandang disabilitas tunarungu dengan responden normal pada hal tempat duduk prioritas dan keberadaan petugas. Hal ini terjadi pada bagian sarana dan prasarana. Para penyandang disabilitas tunarungu selalu meletakkan keberadaan petugas sebagai hal yang paling penting pada sarana dan prasarana transportasi kota serta menaruh tempat duduk prioritas sebagai hal yang tingkat kepentingannya paling rendah. Sedangkan para responden normal selalu meletakkan tempat duduk prioritas sebagai suatu hal yang 
penting bagi para penyandang disabilitas tunarungu dan menaruh keberadaan petugas pada hal yang tidak terlalu dibutuhkan oleh para penyandang disailitas tunarungu.

3. Tingkat ketersediaan sarana, prasarana, dan prasarana pejalan kaki transportasi kota (KRL Commuter Line Jabodetabek, Transjakarta, MRT Jakarta) sudah cukup tersedia. Hanya tempat duduk prioritas pada halte transjakarta yang belum cukup tersedia. Sarana dan prasarana MRT Jakarta menjadi yang paling baik dalam hal ketersediaan untuk transportasi kota di Jabodetabek. Para responden penyandang disabilitas tunarungu memberikan nilai untuk tingkat ketersediaan lebih tinggi dari pada para responden normal untuk setiap hal. Hal ini menunjukkan bahwa para penyandang disabilitas tunarungu lebih puas terhadap ketersediaan sarana, prasarana, dan prasarana pejalan kaki daripada para responden normal.

\section{Saran pemanfaatan penelitian}

Berdasarkan penelitian dan penarikan kesimpulan yang telah dilakukan dapat direkomendasikan saran terhadap pemanfaatan penelitian ini, yakni:

1. Penelitian ini dapat digunakan sebagai pertimbangan dalam merencanakan transportasi kota di daerah Jabodetabek dalam rangka pembuatan atau perbaikan sarana, prasarana, dan prasarana pejalan kaki transportasi kota

2. Tingkat kepentingan sarana, prasarana, dan prasarana pejalan kaki transportasi kota dalam peneletian ini dapat digunakan sebagai acuan sarana, prasarana, prasarana pejalan kaki transportasi kota apa yang harus lebih diperhatikan untuk ditingkatkan dalam membuat atau memperbaiki transportasi kota di Jabodetabek untuk para penyandang disabilitas tunarungu.

3. Hasil Penelitian ini dapat digunakan sebagai bahan tinjauan pustaka untuk penelitian-penelitian yang mempunyai tema yang sama dengan penelitian ini.

4. Hasil Penelitian ini dapat digunakan untuk bahan pertimbangan peraturan pemerintah untuk para penyandang disabilitas pada transportasi kota.

\section{Saran terhadap penelitian selanjutnya}

Berdasarkan penelitian yang sudah dilakukan dapat direkomendasikan saran terhadap penelitian selanjutnya, yakni:

1. Jumlah Responden penelitian yang menyandang disabilitas tunarungu sebaiknya diperbanyak agar hasil dari penelitian lebih akurat.

2. Bahasa Pertanyaan yang digunakan dalam kuesioner lebih baik jika disederhanakan sehingga para penyandang disabilitas tunarungu dapat dengan mudah mengerti pertanyaan kuesioner yang ditanyakan. Hal ini dikarenakan para penyandang disabilitas tunarungu mempunyai kekurangan di dalam memahami sebuah kalimat.

3. Penelitian dilakukan terhadap lebih banyak responden agar hasil penelitian lebih mewakili dari kebutuhan para penyandang disabilitas tunarungu.

\section{DAFTAR PUSTAKA}

ITDP. Panduan Desain Fasilitas Pejalan Kaki : DKI Jakarta 2017-2022. 2019, Jakarta

KCJ. PT KCJ TERUS PENUHI FASILITAS PENUMPANG DENGAN DISABILITAS. KRL, 19 Februari 2016, Jakarta. http://www.krl.co.id/pt-kcj-terus-penuhi-fasilitas-penumpang-dengan-disabilitas/ (Diakses pada tanggal 2 September 2019)

Mathers C.D., et al. "Global Burden of hearing loss in the year 2000". GBD 2000 Working Paper, WHO, 2003, Geneva

Saaty, T.L., and Luis G. Vargas. Models, Methods, Concepts and Applications of the Analytic Hierarchi Process. $2^{\text {nd }}$ ed., Springer, 2012

Saaty, T.L. Pengambilan Keputusan. Cetakan Ke-II., PT. Pustaka Binaman Persindo, 1993, Jakarta

UU No. 19 Tahun 2011 tentang Pengesahan Convention On The Rights Of Persons With Disabilities (Konvensi Mengenai Hak-Hak Penyandang Disabilitas)

Waara et al,. "Feasible Provision of Targeted Traveler Information in Public Transportation: Segmentation Based on Functional Limitations". Transportation Research Part A. vol.74, 2015, pp. 164-173 